\title{
Tanulmányok
}

\section{ONKOREUMATOLÓGIA: ÖSSZEFOGÁS A TÁRSSZAKMÁK KÖZÖTT A TUDOMÁNYBAN ÉS A GYÓGYÍTÁSBAN}

\section{ONCORHEUMATOLOGY: COOPERATION BETWEEN MEDICAL SPECIALTIES IN RESEARCH AND PATIENT CARE}

\author{
Szekanecz Zoltán ${ }^{1}$, Szekanecz Éva² \\ ${ }^{1}$ tanszékvezető egyetemi tanár \\ Debreceni Egyetem Általános Orvostudományi Kar Belgyógyászati Intézet Reumatológiai Tanszék, Debrecen \\ szekanecz.zoltan@med.unideb.hu \\ ²egyetemi adjunktus, Debreceni Egyetem Általános Orvostudományi Kar Onkológiai Klinika, Debrecen
}

\begin{abstract}
ÖSSZEFOGLALÁS
Az onkoreumatológia a daganatképződés és a reumatológiai kórképek kapcsolatát jelenti. Számos összefüggés van a két orvosi szakterület között. Ezek egy része a reumatológiai kórképben szenvedő betegben jelentkező daganatokat, a másik fele pedig a daganatos betegben fellépő mozgásszervi tüneteket foglalja magában. Az előbbi csoporthoz soroljuk a reumatológiai betegségekben jelentkező másodlagos daganatokat, a tumorasszociált antigének reumatológiai szerepét, a mozgásszervi betegségek kezelésére használt hagyományos és célzott terápiák esetleges karcinogenitását és a korábban vagy jelenleg daganatos, mozgásszervi betegek fizioterápiáját. A másik nagy csoport magában foglalja a paraneopláziás szindrómákat, az onkológiai kezelések (kemoterápia és immunterápia) lehetséges autoimmun-reumatológiai mellékhatásait, a hormonmegvonási kezelés csonthatásait és a mozgásszervrendszer daganatait.
\end{abstract}

\section{ABSTRACT}

Oncorheumatology is the meeting point of tumour formation and rheumatic diseases. Multiple interactions exist between these two medical specialities. One major field is the topic of malignancies associated with rheumatic diseases, while the other topic covers the development of musculoskeletal disease in cancer patients. Within the first group, secondary malignancies associated with rheumatic diseases, the role of tumour-associated antigens in rheumatology, the possible carcinogenicity of conventional and biologic antirheumatic drugs and physical therapy of rheumatic patients with recent or current cancer will be discussed. The second large topic includes paraneoplastic syndromes, autoimmune-rheumatic side effects of oncological therapies (chemotherapy and immunotherapy), effects of hormone-deprivation therapies on bone and primary and secondary malignancies of the musculoskeletal system. 
Kulcsszavak: onkoreumatológia, mozgásszervi betegségek, daganatok, másodlagos daganatképződés, karcinogenitás, célzott terápia, immuncheckpoint-gátlók, szarkómák

Keywords: oncorheumatology, musculoskeletal diseases, tumours, secondary tumour development, carcinogenicity, targeted therapy, immune-checkpoint inhibition, sarcomas

\section{BEVEZETÉS AZ ONKOREUMATOLÓGIÁBA}

A medicinára egyre inkább a multidiszciplináris jelleg jellemző. Mindez kiemelten vonatkozik a reumatológiára és onkológiára, melyek számos társszakmával állnak kapcsolatban. Mindennek fontos szerepe lehet mind a kutatás, mind a klinikum szempontjából (1. ábra; 1. táblázat). Az onkoreumatológia a daganatképződés és a mozgásszervi kórképek találkozását jelenti. Számos kapcsolódási pont van a két orvosi szakterület között (1. ábra; 1. táblázat). Ebben a közleményben, a teljesség igénye nélkül, áttekintjük a főbb, mind a kutatás, mind a klinikai gyakorlat számára fontos kapcsolódási pontokat (Szekanecz É., 2019).

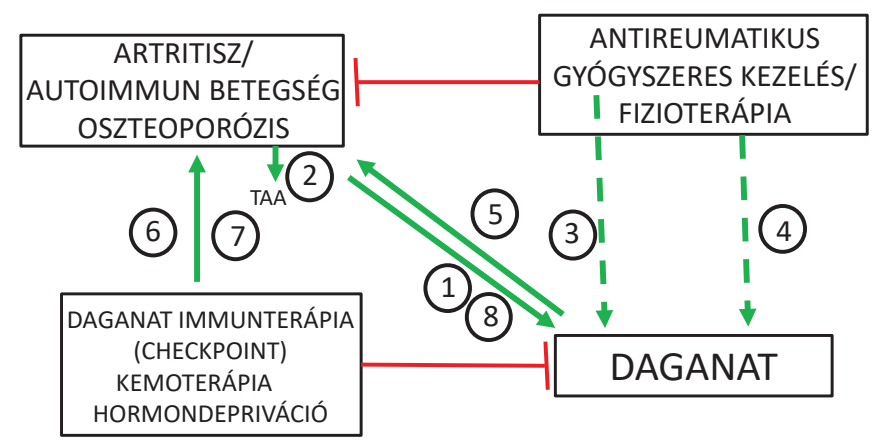

1. ábra. Az onkoreumatológia összefüggései

Az ábrán nyíllal a pozitív (serkentő), a $\vdash$ jellel a gátló folyamatok látszanak. A reumatológiai kórképekhez szekunder tumorok társulhatnak (1). A gyulladásos kórképeket is kísérheti az adhezív tulajdonságú tumorasszociált antigének (TAA) fokozott termelődése (2). A reumatológiában főleg korábban alkalmazott gyógyszeres (3) és nem gyógyszeres kezelés (fizioterápia) (4) esetében felmerül a karcinogenitás és a daganat kiújulása, ami miatt óvatosság indokolt. A malignus daganat és az általa termelt mediátorok paraneopláziás szindrómát okozhatnak (5). A daganat immunterápia és a kemoterápia autoimmun jelenségeket (6), a nemihormon-megvonásos kezelés pedig oszteoporózist okozhat (7). Végül, fontosak a mozgásszervrendszer (támasztószövet) primer és szekunder daganatai is (8). 
1. táblázat. Az onkoreumatológia pillérei

\begin{tabular}{|c|}
\hline REUMATOLÓGIAI BETEGSÉG $\rightarrow$ DAGANAT \\
\hline $\begin{array}{l}\text { 1. Szekunder malignitások reumatológiai kórképekben } \\
\text { 2. Tumorasszociált antigének reumatológiai betegségekben } \\
\text { 3. Daganatképződés/daganatkiújulás reumatológiai gyógyszeres terápia mellett } \\
\text { 4. Nem gyógyszeres kezelés (fizioterápia) mozgásszervi, daganatos betegben }\end{array}$ \\
\hline DAGANAT $\rightarrow$ REUMATOLÓGIAI BETEGSÉG \\
\hline $\begin{array}{l}\text { 5. Paraneopláziás szindrómák } \\
\text { 6. Autoimmun/reumatológiai kórképek onkoterápia mellett } \\
\text { 7. Oszteoporózis nemihormon-gátló kezelés mellett } \\
\text { 8. A mozgásszervrendszer tumorai }\end{array}$ \\
\hline
\end{tabular}

(A magyarázatot lásd a szövegben.)

\section{REUMATOLÓGIAI KÓRKÉPEK ONKOLÓGIAI VONATKOZÁSAI}

\section{Másodlagosan kialakuló malignitások reumatológiai kórképekben}

A reumatológiai betegségekben krónikusan fennálló gyulladás rosszindulatú daganatos betegségeket provokálhat. A hatékony reumatológiai kezelések következtében a kezelt betegek élethossza jelentősen megnyúlt, így lehetőség nyílik, akár évtizedek múlva is, egy másodlagos daganat kifejlődésére (Szekanecz É. et al., 2006).

Számos reumatológiai kórképben (például: reumatoid artritisz, RA; juvenilis idiopátiás artritisz, JIA; szisztémás lupusz eritematózusz, SLE; szisztémás szklerózis, SSc [scleroderma]; Sjögren-szindróma, SS; dermatomioszitisz, DM) a tartós B-sejt-stimuláció a betegek egy részében rosszindulatú vérképzőszervi betegség, leginkább non-Hodgkin-limfóma (NHL) kialakulásához vezethet (Nakken et al., 2012). Emellett, a gyulladás által érintett célszervekben (például SSc-ben tüdő, bőr) gyakrabban alakulnak ki tumorok (Szekanecz Z. et al., 2011). Konkrétan, RA-ban az NHL átlagosan tizenkétszeres incidencianövekedése figyelhetö meg, míg a leggyakoribb szolid daganat, a tüdőrák kb. 25\%-kal gyakoribb az átlagpopulációhoz képest. Utóbbi kialakulásában a dohányzás, amely mind a daganat, mind az RA patogenezisének sarokköve, elsődlegesen fontos. RA-ban az emlö- és méhnyakrák szintén gyakoribb, ám a vastagbél- és gyomorrák vonatkozásában, valószínủleg a nem szteroid gyulladásgátlók (NSAID) szedése miatt is, kisebb a rizikó. SSc-ben az NHL kockázata tízszeresére nőtt. A szolid tumorok szintén a gyulladás és szöveti fibrózis által leginkább érintett szervekben (tüdö, 
bőr, nyelőcső) jelentkeznek. DM-ben az emlö-, tüdő- és a gyomorrák jelentkezik gyakrabban. SLE-ben az NHL, az emlörák, tüdőrák és epeúti rosszindulatú tumorok gyakorisága emelkedett. Az NHL kialakulásában az Epstein-Barr-vírusnak (EBV) fontos szerepe van. SS-ben egyértelmüen a limfoproliferatív kórképek a gyakoribbak. Ebben a tartós B-sejt-stimuláció játszik kiemelt szerepet. A limfadenopátia, az elhúzódó fültőmirigy duzzanat daganatképződésre hajlamosító tényezők (Szekanecz Z. et al., 2011).

A fentiekkel ellentétben, a gerinc gyulladásos betegségeiben (szpondilitisz ankilopoetika [Bechterew-kór] és artritisz pszoriatika) nem észlelték az alapbetegség következtében kialakuló malignitások fokozott rizikóját (Szekanecz É. et al., 2006).

Saját korábbi felmérésünkben, 516 RA-s betegből 13 esetben alakult ki rosszindulatú daganat. A leggyakoribb (6 eset) tüdőrák volt, de pajzsmirigy-, epehólyag-, hasnyálmirigy-, emlö- és vastagbélrák, valamint NHL eseteink is voltak. Szklerodermában $218 \mathrm{SSc}-\mathrm{s}$ beteg közül 11 esetben alakult ki tumor, úgymint NHL, tüdő-, emlö-, nyelőcső-, bőr-, méhnyakrák és leiomioszarkóma. Ismeretes, hogy a fibrózis a tüdőt, bőrt és nyelőcsövet érinti. Megjegyzendő, hogy a daganatos esetek között volt olyan, aki megelözően karcinogén hatásáról ismert azathioprint (AZA) vagy cyclophosphamidot (CYC) kapott (Szekanecz Z. et al., 2011).

Ami a sejtes és molekuláris immunológiai mechanizmusokat illeti, röviden, a krónikus gyulladás genetikai eltérések, szöveti károsodás, fokozott sejtszaporodás, daganatinvázió és áttétképzés révén vezet daganatképződéshez és -terjedéshez (Elinav et al., 2013). Alapvető kérdés, hogy amikor az akut gyulladás idültté válik, utóbbi miért nem a gyulladáscsökkenés, hanem inkább a daganatképződés irányába halad? A gyulladást kiváltó ingerek fennmaradása fenntarthatja az elhúzódó gyulladást. Emellett, többek között a mutációk, a programozott sejthalál (apoptózis) károsodása, a növekedési faktorok, fokozott érújdonképződés (angiogenezis), hormonális és epigenetikus (környezeti) faktorok is szerepet játszhatnak a krónikus gyulladás daganat irányú átalakulásában (Elinav et al., 2013). Ismeretes, hogy direkt összefüggés van a gyulladásos aktivitás és a malignitás rizikója között (Baecklund et al., 2006).

A gyulladásos sejtek közül a monociták/makrofágok által termelt gyulladásos fehérjék (tumornekrózis-faktor $\alpha$ [TNF- $\alpha$ ], interleukin 1 [IL-1] és IL-6) gátolják a hámsejtek érését, és serkentik a daganatos átalakulást. A TNF- $\alpha$, IL-1, IL-13 egyrészt a p53 és Myc onkogének átíródását, másrészt a hipoxiaindukált faktor $1 \alpha$ (HIF-1 $\alpha$ ) és a vaszkuláris endoteliális növekedési faktor (VEGF) stimulációja révén a tumor angiogenezist serkentik. Az IL-6 a STAT3 aktivációján keresztül egyéb onkogének kifejeződését is növeli (Elinav et al., 2013).

Másfelöl, a kialakult tumorok visszahatva, átalakítják a gyulladásos szöveti környezetet. A daganatsejtek olyan anyagokat, köztük növekedési faktorokat 
termelnek, amelyek visszahatva a daganat ellen támadó T-sejtekre, végső soron a tumorellenes immunreakciókat gátolják, ami kedvez a daganatnövekedésnek. A tumorellenes $\mathrm{T}_{\mathrm{H}} 1$ sejtek helyett immungátló szabályzó $\mathrm{T}$-sejtek $\left(\mathrm{T}_{\mathrm{REG}}\right)$ szaporodnak fel. Ez a tumor elleni sejtes immunválasz gátlása révén szintén a tumor növekedésnek kedvez (Elinav et al., 2013).

Összességében tehát az idült gyulladásos környezet sejtjei és fehérjéi révén kedvez a tumorok növekedésének és terjedésének. Másfelől, a daganatsejtek a tumorellenes gyulladásos reakció átprogramozásával visszaszorítják a daganatellenes védekezést. Ez a kölcsönhatás, mint ördögi kör - amíg terápiásan nem avatkozunk be - folyamatos daganatnövekedést eredményez. Az is egyértelmü, hogy mind a háttérben húzódó gyulladásos betegség gátlása, mind az onkológiai terápia megszakíthatja ezt a kört (Elinav et al., 2013).

Külön szóljunk a „B-sejtes”, autoantitest termeléssel járó betegségekben (például RA, SLE, SSc, SS, DM) kialakuló limfómákról. Az autoimmunitásból a daganat irányába történő átalakulásában genetikai tényezők, környezeti faktorok (például fertőzések, gyógyszerek, vegyszerek) és immunológiai eltérések állnak. Utóbbiakra jellemző, hogy a szekunder immunhiány, a $T_{\text {REG }}$ sejtek defektusa, a $\mathrm{T}_{\mathrm{H}} 1 / \mathrm{T}_{\mathrm{H}} 2$ arány megváltozása, a citokinek túltermelódése mind szerepet játszanak. A B-sejtes autoimmunitás és a limfómák kialakulásában fontos a B-sejt-aktiváló faktor (BAFF) rendszer. Ez, mint ellenőrzőpont (checkpoint) ugyancsak részt vesz a centrális és perifériás immuntoleranciában. Egyrészt, csökkent müködése kedvez a „B-sejtes” kórképek kialakulásának. Nem véletlen, hogy a BAFF-gátló belimumab bevethető mind autoimmun kórképekben (például SLE), mind B-sejtes limfómákban (Nakken et al., 2012).

Újabban az derült ki, hogy az esetek 20\%-ában a bél mikrobiom is szerepet játszik e folyamatokban. A mikrobiális antigéneket felismerő Toll-like receptorok (TLR) és a MYD88 fehérje vastagbélrákban betöltött szerepét kolitiszes egértörzsben igazolták. Később humán vizsgálatok valószínűsítették az E. coli, valamint egyes Fusobacterium és Bacteroides fajok szerepét a gyulladásos bélbetegséghez kapcsolódó vastagbélrák patogenezisében. Valószínúleg a reumatológiai kórképekben is hasonló folyamatok játszódnak le (Catrina et al., 2016).

\section{Tumorasszociált antigének reumatológiai betegségekben}

A napi laboratóriumi rákdiagnosztikában is használatos tumorasszociált antigének (TAA) általában szénhidráttartalmú fehérjék, melyek a tumorsejtek tapadásában (adhézió) és a tumorinvázióban vesznek részt. A mért TAA-k a karcinoembrionális antigén (CEA), valamint a CA19-9, CA125, CA15-3 és a CA72-4. Ezek a molekulák a tumorsejtek felszínén helyezkednek el, majd onnan leválva kimutathatók a betegek vérében. Az egyes TAA-k különböző daganattípusokra jellemzőek (Szekanecz É. et al., 2006). 
Néhány évtizeddel ezelött kiderült, hogy a TAA-k a tumorsejtek mellett a gyulladásos fehérvérsejtek felszínén is megjelennek. Magunk elsők között mutattuk ki a CEA expresszióját az RA-s betegek ízületi fehérvérsejtjein. A szolubilis TAA-k magasabb vérszintet mutathatnak bizonyos gyulladásos-autoimmun megbetegedésekben (Szekanecz É. et al., 2006).

Korábbi kutatásaink során több TAA szérumszintjét határoztuk meg RA-ban, SSc-ben és SLE-ben. Több RA-s betegben volt kórosan emelkedett CA125, CA19-9 és CA15-3 a kontrollokkal összevetve. Több SSc-s betegnek volt abnormisan magas CA19-9, CA125 és CA15-3, valamint több SLE-s betegnek kórosan magas CEA, CA19-9, CA125 és CA72-4 szintje a kontrollhoz képest. SSc-ben több TAA vérszintje összefüggött a veseérintettséggel, artritisszel, és a C-reaktív proteinnel (CRP), míg SLE-ben a szérum TAA-koncentrációk összefüggést mutattak a központi idegrendszeri tünetekkel és az SLE betegségaktivitási indexszel (Szekanecz É. et al., 2006).

A napi gyakorlat számára az a tanulság, hogy autoimmun gyulladásos reumatológiai betegekben a TAA-k vérszintjének mérését daganatgyanú esetén nagy óvatossággal kell végezni és értékelni (Szekanecz É. et al., 2006)!

Daganatképződés és kiújulás reumatológiai gyógyszeres terápia mellett

Mint láttuk, a reumatológiai kórképekben megfigyelhető általánosult gyulladás fokozza a daganatrizikót. Másfelől azonban, néhány reumaellenes gyógyszer esetében felmerült, hogy karcinogén lehet (Ramiro et al., 2014). Ezt a látszólagos ellentmondást nagy betegregiszterekben végzett sorozatos elemzések válaszolhatják meg, amelynek során időben összevetik az évtizedekkel ezelőtti adatokat a mostaniakkal (Ramiro et al., 2014). Nagyon fontos tényező, hogy az alapbetegség gyulladásos aktivitása valószínüleg sokkal fontosabb a daganatképződés szempontjából, mint a szedett gyógyszerek (Baecklund et al., 2006).

CYC-t, AZA-t és cyclosporin A-t (CsA) ízületi gyulladásban ma már csak nagyon ritkán, inkább szisztémás vaszkulitiszekben, SSc-ben, SLE-ben, mioszitiszekben adnak. Az Egyesült Királyság nagy regiszterében végzett elemzés alapján az AZA, CYC vagy CsA szedése esetén a daganatrizikó (RR) 1,63 (95\% CI: 1,05-2,52) volt. A karcinogenitás összefügg a kezelés tartamával és a gyógyszerdózissal (Szekanecz Z. et al., 2011).

A reumatológiában legszélesebb körben alkalmazott csDMARD a kis dózisú methotrexat (MTX), amely irodalmi áttekintés alapján nem emeli a malignitás kialakulásának rizikóját (Szekanecz Z. et al., 2011). Korábban, a biológiai terápia bevezetése (2016) előtt növekedni látszott MTX-terápia mellett egyes rosszindulatú hematológiai kórképek előfordulása, de ma már valószínűsíthető, hogy ez az EBV-pozitivitással magyarázható inkább, mintsem az MTX adásával. A 2000-es évek elején még aktív gyulladásos, sok társbetegségben szenvedő, más gyógy- 
szerre nem reagáló betegeket kezeltek, így inkább az alapbetegség, mintsem az MTX okozhatta az emelkedett daganatrizikót (Ramiro et al., 2014).

Ugyanez a szemléletváltás vonatkozik a biológiai (célzott) terápiákra is. Ezek a szerek az immunrendszer egyetlen meghatározott pontján hatnak (immunterápia). Az első nagy, 2006-ban végzett svéd felmérésben, összesen hét 2000-2004 között folytatott vizsgálat metaanalízise szerint az RR 3,29 (95\% CI: 1,19-9,08) volt, vagyis a biológiai terápia összességében háromszoros rizikót jelentett (Baecklund et al., 2006). Hasonlóan az MTX-hez, a 2000-es évek elején biológiai szereket is csak inkább végső esetben adtak. (Hazánkban is 2006 óta finanszírozzák a biológiai terápiát.) Ugyancsak 2006-ban erősítették meg, hogy a szisztémás, nem kontrollált gyulladás nagyobb daganatrizikót jelent, mint a biológiai terápia (Baecklund et al., 2006). Ahogy az időben haladva egyre újabb felmérések kerültek napvilágra, úgy csökkent, majd tủnt el a daganatrizikó-emelkedés (Ramiro et al., 2014).

Összességében tehát, a régebbi típusú csDMARD-szerekkel (AZA, CYC, CsA) ellentétben sem az MTX, sem a modern biológiai terápiák nem emelik a daganatrizikót. Utóbbi inkább az alapbetegségnek, a kornak, mintsem a reumatológiai szereknek köszönhetö (Ramiro et al., 2014).

\section{Fizioterápia mozgásszervi, daganatos betegben}

A fizioterápia, elsődlegesen a gyógytorna, lényegében hidat képez két nagy tématerületünk között. Ez esetben ugyanis egyrészt az a kérdés, hogy a reumatológiai beteg kaphat-e fizioterápiát, ha daganata is van/volt, és ez mennyire lehet veszélyes a daganatképződés szempontjából. Másrészt a fizioterápia a daganatos betegség szempontjából is kedvező hatású lehet. Az utóbbi tíz-húsz évben, a daganatos anamnézis abszolút kontraindikációt jelentett fizioterápiás rehabilitáció szempontjából. Ez a szemlélet mára alapvetően megváltozott (Gomez et al., 2016).

Ami a daganatos betegek fizioterápiáját illeti, összesen harmincnégy nagy tanulmány metaanalízise alapján megállapítható, hogy a gyógytorna jelentősen javítja a daganatos betegek fizikai állapotát és életminőségét. Emiatt egyértelmü, hogy azokat a fizioterápiás eljárásokat, amelyek nem ellenjavalltak (lásd később), a daganatos állapot szempontjából is hasznosnak kell értékelnünk. Amennyiben a mozgásszervi alapbetegség kezelése az elsődleges az egyébként daganatos vagy daganatos betegségen átesett betegnél, a kezelés egyéni mérlegelést igényel. Az aktív daganatot el kell különíteni a korábbi, gyógyult daganatos betegségtől. Minden esetben mérlegelni kell az egyéni haszon-kockázat arányt. Az e témában végzett klinikai kutatások eltérő értékủek. Legmagasabb evidenciával a gyógytorna tárgykörében közölt vizsgálatok bírnak. A mozgásterápia mindenképp hasznos. Az ellenjavallatot jelentő állapotokról (például behelyezett tartós szondák vagy katéterek, vérszegénység, csontáttét stb.) az onkológussal kell beszélni. A javasolt 
mozgásformák a panaszok mérséklésén, valamint az általános izomerő és kondíció fokozódása révén javítják az életminőséget. Az egyéb fizioterápiás eljárások közül bizonyos masszázskezelések (például emlőrákosok nyirokmasszázsa) és elektromos kezelések (például TENS) vonatkozásában megengedőbbek a vélemények, bár magas evidenciájú vizsgálatok e témában sem érhetők el. Emlőrákos betegek mütét utáni rehabilitációjában a fürdőkezeléseket (balneoterápia), ingeráram-kezeléseket és ultrahang-terápiát illetően kevesebb a bizonyíték, így ezeket a modalitásokat óvatosan alkalmazzuk. Néhány kezelés (például rövidhullám, hő, galvánáram) pedig daganatos alapbetegség esetén kifejezetten ellenjavallt, mivel a tumorszövet keringését is javítva, kedvezhet a daganat szóródásának (Gomez et al., 2016).

A megbízható evidenciák hiányában tehát minden betegnél a legfontosabb az előny-kockázat arány mérlegelése, és a társszakmák közötti szoros együttmüködés (Gomez et al., 2016).

\section{DAGANATOS BETEGSÉGEK MOZGÁSSZERVI ASPEKTUSAI}

\section{Paraneopláziás szindrómák}

A paraneopláziás („daganat melletti”) szindróma a tumor távolhatása következtében alakul ki. Nem arról van szó, hogy a primer tumor vagy annak áttéte közvetlen módon lép kapcsolatba az érintett szövettel (például csontáttétek helyi fájdalmat okozó hatásai). A daganat, hasonlóan ahhoz, ahogy a gyulladásos környezetben viselkedik (lásd elöbb), hormonokat, gyulladásos fehérjéket, antitesteket termel, ami a szervezet egy másik pontján gyulladásos-autoimmun betegséget vagy más mozgásszervi kórképet utánzó tünetegyüttest vált ki. A gyulladásos mediátorok mellett sejtes reakciók (például citotoxikus T-sejtek) is kiválthatnak ilyen jelenségeket (Manger-Schett, 2014). A paraneopláziás mozgásszervi tünetekre jellemző, hogy általában az onkológiai diagnózis előtt (akár több évvel is!) már vannak a betegnek gondozást igénylö, lassú progressziójú, általában aszimmetrikus panaszai, melyet antireumatikus terápiával kezelnek. Nemegyszer annak hatástalansága és egyéb daganatra utaló általános tünetek (láz, fájdalom, izom- és általános gyengeség, fogyás, fáradékonyság) vetik fel egyéb, esetleges malignus betegség lehetőségét a háttérben (2. táblázat) (Manger-Schett, 2014). Ugyancsak fontos, hogy a paraneopláziás jelenségek a daganat eltávolítása esetén csillapodnak (Manger-Schett, 2014).

A paraneopláziákat a 2. táblázatban bemutatott csoportokra oszthatjuk. A klinikai tünetcsoportok ennek megfelelően lehetnek artritiszek, szisztémás autoimmun kötőszöveti szindrómák, vaszkulitiszek, bőr- és izombetegségek, anyagcsere-betegségek. A felsorolt paraneopláziák nagyon hasonlítanak a megfelelö 
kórképre. De az „RA-like”, „lupus-szerü” vagy „cancer-associated myositis” jelleg arra utal, hogy nem teljes mértékben felelnek meg a klasszikus betegségeknek. Magukat a kórképeket itt most nem részletezzük (2. táblázat) (MangerSchett, 2014).

2. táblázat. Reumatológiai paraneopláziás szindrómák

\begin{tabular}{|l|}
\hline Autoimmun kötőszöveti betegségek \\
\hline - Polimioszitisz, dermatomioszitisz \\
- Lupus-szerủ szindróma \\
- Szkleroderma-szerú szindróma \\
\hline Artritiszek \\
\hline - Hipertrófiás oszteoartropátia (szekunder) \\
- Karcinóma poliartritisz (RA-szerü betegség) \\
- Rekurráló polikondritisz \\
- RS3PE-szindróma \\
\hline Paszkulitiszérisz fasciitisz és poliartritisz \\
\hline - Atípusos polimalgia reumatika \\
- Eritéma nodózum \\
\hline Krioglobulinémiás vaszkulitisz \\
\hline Bör- és izombetegségek \\
\hline - Dermatomioszitisz \\
- Lambert-Eaton-szindróma \\
- Palmárisz fasciitisz \\
- Eannikulitisz \\
\hline Anyagcsere-betegségek \\
\hline Köszvény \\
\hline
\end{tabular}

(A magyarázatot lásd a szövegben.)

Ami a sejtes és molekuláris kialakulást illeti, egyetlen példát említve, klasszikus lehet a hipertrófiás oszteoartropátia (HOA). Ez a „tankönyvi” paraneoplázia tüdőrákhoz szokott társulni. A kézujjak vége megvastagszik, „dobverőujj” alakul 
ki. Az utóbbi tünet a tumor által termelt érképző (angiogén) mediátorok, elsősorban a VEGF és trombocita eredetü növekedési faktor (PDGF) stimuláló hatásából ered. Ennek következtében a lágyrészek vizenyősek lesznek, szöveti fibrózis alakul ki, és a csonthártya megvastagodik, ami a jellegzetes klinikai képet okozza (Szekanecz Z. et al., 2011).

\section{Autoimmun-reumatológiai kórképek daganatterápia mellett}

\section{Hagyományos kemoterápiás szerek}

Már a hagyományos kemoterápiás szerek mellett is tapasztalhatók reumatológiai jellegü mellékhatások, amelyek általában a kezelés után néhány héttel vagy hónappal jelentkeznek. A panaszok (ízületi és izomfájdalom, reggeli ízületi merevség, a kéz kisízületek, a boka, térd duzzanata) rendszerint nem gyulladásos jellegűek, vándorló fájdalmak, és egy év alatt maguktól elmúlnak. Leggyakrabban a CYC, 5-fluorouracil (5-FU), tamoxifen, MTX és cisplatin okoz ilyen komplikációkat. A bleomycin, vinca-alkaloidák és a platinaszármazékok Raynaud-szindrómát (a kézujjak és lábujjak hidegre jelentkező elkékülését), az 5-FU, a cisplatin, CYC, MTX, az aromatázgátlók és a tamoxifen ízületi és izomfájdalmat okozhatnak, amelyek fiatal korban jelentkeznek. Ezekre a panaszokra kezdetben fájdalomcsillapító (paracetamol) vagy NSAID, később akár kortikoszteroid kezelés is szükségessé válhat (Szekanecz É., 2019).

\section{Immuncheckpoint-gátlók (immunterápia)}

Az immun-ellenőrzőpontok, más néven immun-checkpointok az immunrendszer aktivációjának szabályozó fehérjéi. Az immunreakció, jelen esetben a daganatellenes immunitás kezdeti alapvető lépése, amikor az antigén-prezentáló sejtek (APC; például dendritikus sejtek [DC]; makrofágok) a (tumor)antigént bemutatják a T-sejtnek. Ezt követően a T-sejt felismeri és - optimális esetben - elpusztítja a daganatsejtet. Ismeretes, hogy az antigén-felismerés során a leírt elsődleges felismerési mechanizmus mellett egy második, serkentő (kostimulációs) jel is szükséges a folyamathoz. Amennyiben az APC B7-1 antigénje a T-sejt CD28 molekulájához kötődik, pozitív szignál (kostimuláció) jön létre, a T-sejt aktiválódik, és elindul a tumorellenes immunválasz. Ha azonban az APC-n levő B7-2 molekula a T-sejt CTLA4 molekulájával, vagy az APC programmed death ligand 1 (PD-L1) molekulája a T-sejt PD-1 receptorával kapcsolódik, negatív, gátló szignál (koinhibíció) jön létre, T-sejt reakcióképtelenség alakul ki, és a daganatellenes immunreakció elmarad (Szekanecz É.-Szekanecz Z., 2019).

Kimutatták, hogy egyes daganatokban a tumorellenes immunválaszt gátló CTLA4, illetve PD-1/PD-L1 molekulák szöveti megjelenése fokozott. Ez is a daganat egyik védekezési módja az immunválasz ellen (Chinai et al., 2015). A tumor 
elleni sikeres védekezés érdekében tehát ezt a koinhibíciót kell gátolnunk az immun-checkpoint molekulák elleni antitestekkel (,a gátlás gátlása”), amely révén a T-sejt-felismerés felszabadul a gátlás alól, és a tumorellenes immunitás helyreáll. A koinhibíciót gátló, ezáltal a tumor elleni védekezést javító CTLA4, PD-1 vagy PD-L1 elleni antitesteket (ellenanyagokat) hívjuk immuncheckpoint-inhibitoroknak (ICI) (Chinai et al., 2015). A jelenleg törzskönyvezett ICI-k közé tartozik a CTLA4-gátló ipilimumab, a PD-1-gátló nivolumab és pembrolizumab, valamint a PD-L1-gátló atezolizumab, avelumab és durvalumab. E gyógyszerek és más daganatellenes szerekkel történő kombinációik javallatai közül kiemelendő az áttétes melanóma és a tüdőrákok, de fej-nyaki laphámrákok, máj-, vese-, húgyhólyagrák, illetve Hodgkin-kór is (Szekanecz É.-Szekanecz Z., 2019).

Az ICI-k mellékhatásprofilja teljesen eltér az eddig megszokott, „klasszikus” kemoterápiák és a molekulárisan célzott kezelések okozta jelenségektől. Mivel az ICI-k célpontja nem a daganatsejt maga, hanem a gazdaszervezet immunrendszere, az egyre gyakrabban felismert autoimmun mellékhatások (immune-related autoimmune event, IRAE) a védekező rendszer aktiválódása következtében jönnek létre (Szekanecz É.-Szekanecz Z., 2019). Ami az ICI-kezelés mellett jelentkező IRAE-k mechanizmusait illeti, röviden, a PD-1-, PD-L1- és CTLA4-gátlás következtében daganatellenes T-sejtekben fokozódik az mTOR (sejtnövekedés és fehérjeszintézis), Bcl-xL (sejttúlélés) és Ras- (sejtproliferáció) sejten belüli jelátvitel. Emellett anyagcsere-változások (a glikolízis fokozódása) is bekövetkeznek. Az ICI-gátlók ezen és más mechanizmusokon keresztül serkentik a tumorellenes immunválaszban részt vevő T-sejtek sejtanyagcseréjét, növekedését és túlélését. Ezáltal fokozódik a daganatok elleni T-sejt-válasz, de ezzel párhuzamosan bizonyos autoimmun jelenségek (IRAE) is felerősödhetnek. Az IRAE-k tekintetében alapvető a $\mathrm{T}_{\mathrm{H}} 17-\mathrm{T}_{\mathrm{REG}}$ egyensúly eltolódása az autoimmunitást serkentő $\mathrm{T}_{\mathrm{H}} 17$-sejtválasz irányában, valamint egyes autoantitestek és gyulladásos mediátorok (TNF- $\alpha$, IL-1, IL-6, IL-17, interferon $\gamma$ ) fokozott termelődése (Chinai et al., 2015). Az autoimmun betegségek állatmodelljeiben végzett vizsgálatok során a PD1-gén hiánya vagy a PD-1 és PD-L1 gátlása fokozta különböző típusú ízületi gyulladások, az SLE és az autoimmun diabétesz kialakulását. Emberben RA-ban és más gyulladásos reumatológiai betegségekben, hasonlóan a daganatok egy részéhez, a PD-1 és PD-L1 fokozott kifejeződése mutatható ki az egészségesekhez képest, ami a már elindult autoimmunitást gátló mechanizmus indikátora (Szekanecz É.-Szekanecz Z., 2019).

Ami a klinikai tüneteket illeti, az IRAE-k viszonylag hamar, a kezelés indítása után már a kezelés első három hónapjában kezdődnek. Ezek a mellékhatások csaknem valamennyi szervet érinthetik, beleértve a mozgásszerveket (artritisz, mioszitisz), légző- (pneumonitisz), gyomor-bél rendszert (bélgyulladás), belső elválasztású mirigyeket (pajzsmirigy, agyfüggelékmirigy, cukorbetegség), idegrendszert (polineuropátia, demielinizáció, arcidegbénulás, miaszténia, mielitiszek, 
aszeptikus meningitisz, Guillain-Barré-szindróma), a kültakarót (bőrviszketés, kiütések), sokkal ritkábban a szemet (uveitisz, keratitisz, dacriadenitisz, retinopátia), a vesét (nefritisz) és a májat is (hepatitisz) (Szekanecz É.-Szekanecz Z., 2019).

Az IRAE-k kezelése és a követés során ICI-kezelés előtt, illetve a kezelés alatt rendszeresen dokumentálni és ellenőrizni kell a beteg tüneteit. Egy javasolt kezelési algoritmus alapján a legenyhébb tünetek esetén az ICI-terápia általában folytatható, de már enyhe tünetek esetén is szorosan kell kontrollálni a beteget. Középsúlyos IRAE esetén az ICI-kezelést átmenetileg felfüggesztjük, és ilyenkor már szteroidkezelés javasolt, a súlyosságnak megfelelő adagban. Ha a tünetek csökkennek, illetve elmúlnak, akkor az ICI-kezelés óvatosan újraindítható. Súlyos, esetleg életet veszélyeztető IRAE esetén az immunterápia végleges abbahagyása, a beteg kórházi kezelése, nagy dózisú szteroid, szükség esetén más immungátló szerek (például MTX, biológiai terápia) adása jön szóba (Leipe-Mariette, 2019).

\section{Csontritkulás hormonmegvonásos kezelés mellett}

Ismeretes, hogy a csontállomány megőrzésében mind a női, mind a férfi nemi hormonoknak szerepük van. Az emlö- és a prosztatarák és egyéb nemi szerveket érintő tumorok kezelésében az ösztrogének (női nemi hormonok) termelődését csökkentő aromatázgátlók és a férfi nemi hormonok szintjét csökkentő antiandrogén szerek fontos szerepet töltenek be. Ezen nemi hormonok gátlása a daganatterápiában a csontbontás fokozódásához és oszteoporózishoz (csontritkuláshoz) vezet. Emlőrákban az aromatázgátlók, prosztatarákban az androgénellenes terápia hatására fokozott csontvesztést és emelkedett csonttörési rizikót tapasztaltak (Coleman et al., 2013).

Ami a mechanizmusokat illeti, daganatos betegben egyszerre érvényesülnek a tumor és a daganatellenes kezelés csonthatásai. Az aromatázgátló és antiandrogén kezelés hatására az ösztradiol és az androgének fent leírt, a csontbontás gátlására és a csontképzés serkentésére irányuló hatásai visszafordulnak. Ennek megfelelően az oszteoklasztok (csontfalósejtek), felszabadulva a gátlás alól, aktiválódnak, ami fokozott csontbontást eredményez. Ráadásul a csont bontása során olyan gyulladásos fehérjék szabadulnak fel, amelyek a tumor növekedéséhez vezethetnek (Coleman et al., 2013).

Mindezek miatt a daganatos betegeket csontsürüség-vizsgálatnak (denzitometriás szürésnek, DEXA) kell alávetni, és a leletnek megfelelően kezelni. Klinikai adatok elsősorban a biszfoszfonátok (főleg zoledronát, ibandronát) és az oszteoklasztok müködését gátló antitest (denosumab) vonatkozásában érhetők el. Emlörákban az aromatázgátló kezelés hatására már 24-26 hónap után jelentős csontvesztés következik be, amit a fenti gyógyszerekkel ki lehet védeni (Coleman et al., 2013). 


\section{A mozgásszervrendszer tumorai}

Természetesen maguk a mozgásszervrendszer daganatai is érinthetik a reumatológiai praxist. Ezen összefoglalónak azonban végképp nem lehet célja e hatalmas onkológiai terület áttekintése (Pápai, 2002). Itt a reumatológiai gyakorlatot érintő főbb ismereteket foglaljuk össze röviden.

Szövettani szempontból a mozgásszervrendszer tumorai igen heterogén csoportot képviselnek. Összefoglaló néven szarkómáknak hívjuk őket. Ezek a daganatok a malignus szolid tumorok kb. 0,5-1\%-át teszik ki. Bármely életkorban megjelenhetnek, de gyermekkorban gyakoribbak. Prognózisuk igen rossz: a mütét utáni kiújulási arány és az öt éven túl megjelenő távoli áttétek aránya is 50\% körül van. Egyes szarkómatípusok bizonyítottan kromoszómaeltérésekhez és génhibákhoz köthetők. Néhány valószínüsített ok, mely felelőssé tehető szarkómák kialakulásáért: harci gázok, konzerválószerek, gyomirtók, korábbi sugárkezelés, idegentest-beépülés, idült limfödéma, vírusfertőzés, immunhiányos állapotok, traumák. Alapvetően két fő csoportra (lágyrész- és csont-) szokás osztani a szarkómákat (Pápai, 2002).

A klinikum vonatkozásában lokálisan agresszív növekedés, gyors progreszszió és nehéz kezelhetőségük emelhető ki. Tekintettel arra, hogy kb. 45\%-uk az alsó végtagról, azon belül is $75 \%$-uk a térd fölött alakul ki, egyértelmü, hogy hamar okoznak mozgásszervi tüneteket. A szarkómák okozta leggyakoribb tünetek a fájdalom és a végtagi körfogat növekedése (duzzanat). A daganatközeli ízületben hamar kialakul a mozgásbeszükülés, a reaktív ízületi gyulladás is. A láz rossz prognózist jelent. A patológiás törések kockázata 1\% körüli (Pápai, 2002).

A támasztószöveti (mozgásszervi) daganatok oki kezeléseként még mindig a sebészi megoldásnak van a legmagasabb gyógyulási rátája. Nyilvánvaló, hogy a daganatot elsősorban szövettanilag kell igazolni. Megfelelően részletes stádiumbeosztás után kombinált kezeléssel érhető el a legjobb terápiás eredmény. Amennyiben a beteg állapota ezt megengedi, és leletei is az indikációnak megfelelőek, több ciklusból álló kemoterápiás kombinációt (neoadjuváns kezelés) kap a beteg a tervezett mütét előtt, majd a mütét után kiegészítő (adjuváns) kemoterápiát is. A szarkómák a sugárkezelésre általában nem reagálnak (Szekanecz É., 2019).

\section{KÖSZÖNETNYILVÁNÍTÁS}

A munka az Európai Unió Szociális Alap TÁMOP-4. 2. 4. A/2-11/1-2012-0001 „Nemzeti Kiválóság Program” (Sz. Z.); valamint az Európai Unió GINOP-2. 3. 2-15-2016-00050 (Sz. Z. ) támogatásával készült. 


\section{IRODALOM}

Baecklund, E. - Iliadou, A. - Askling, J. et al. (2006): Association of Chronic Inflammation, Not Its Treatment, With Increased Lymphoma Risk in Rheumatoid Arthritis. Arthritis \& Rheumatism, 54, 692-701. DOI: 10.1002/art.21675, https://onlinelibrary.wiley.com/doi/full/10.1002/ art.21675

Catrina, A. - Deane, I. K. D. - Scher, J. U. (2016): Gene, Environment, Microbiome and Mucosal Immune Tolerance in Rheumatoid Arthritis. Rheumatology (Oxford), 55, 391-402. DOI: 10.1093/rheumatology/keu469, https://www.ncbi.nlm.nih.gov/pmc/articles/PMC4746430/

Chinai, J. M. - Janakiram, M. - Chen, F. et al. (2015): New Immunotherapies Targeting the PD-1 Pathway. Trends in Pharmacological Science, 36, 587-595. DOI: 10.1016/j.tips.2015.06.005, https://bit.ly/3fkifeM

Coleman, R. E. - Rathbone, E. - Brown, J. E. (2013): Management of Cancer Treatment-induced Bone Loss. Nature Reviews Rheumatology, 9, 365-374. DOI: 10.1038/nrrheum.2013.36, https://www.researchgate.net/publication/262042760_Management_of_cancer_treatment-induced bone loss

Elinav, E. - Nowarski, R. - Thaiss, C. A. et al. (2013): Inflammation-induced Cancer: Crosstalk between Tumours, Immune Cells and Microorganisms. Nature Reviews Cancer, 13, 759771. DOI: 10.1038/nrc3611, https://www.researchgate.net/publication/258040528_Inflammation-induced_cancer_Crosstalk_between_tumours_immune_cells_and_microorganisms

Gomez I. - Szekanecz É. - Szekanecz Z. et al. (2016): Daganatos betegek fizioterápiája. Orvosi Hetilap, 157, 1224-1231. DOI: 10.1556/650.2016.30502, http://real.mtak.hu/39027/1/650.2016.30502.pdf

Leipe, J. - Mariette, X. (2019): Management of Rheumatic Complications of ICI Therapy: A Rheumatology Viewpoint. Rheumatology (Oxford), 58 Supplement 7, vii49-vii58. DOI: 10.1093/ rheumatology/kez360, https://academic.oup.com/rheumatology/article/58/Supplement_7/vii49/ 5670490

Manger, B. - Schett, G. (2014): Paraneoplastic Syndromes in Rheumatology. Nature Reviews Rheumatology, 10, 662-670. DOI: 10.1038/nrrheum.2014.138

Nakken, B. - Alex, P. - Munthe, L. et al. (2012): Immune-regulatory Mechanisms in Systemic Autoimmune and Rheumatic Diseases. Clinical Developmental Immunology, 2012, 957151. D OI: 10.1155/2012/957151, https://www.hindawi.com/journals/jir/2012/957151/

Pápai Zs. (2002): Prognosztikai faktorok vizsgálata és újabb gyógyszeres kezelési lehetöségek rosszindulatú támasztószöveti daganatok esetén. PhD-értekezés. Budapest: Semmelweis Egyetem, https://bit.ly/2Ytdets

Ramiro, S. - Gaujoux-Viala, C. - Nam, J. L. et al. (2014): Safety of Synthetic and Biological DMARDs: A Systematic Literature Review Informing the 2013 Update of the EULAR Recommendations for Management of Rheumatoid Arthritis. Annals of the Rheumatic Diseases, 73, 529-535. DOI: 10.1136/annrheumdis-2016-210708, https://ard.bmj.com/content/76/6/1101.full

Szekanecz É. (2019): Az onkológiai és reumatológiai kórképek összefüggései. In: Szekanecz Z. Nagy Gy. (szerk.): Reumatológia. Budapest: Medicina, 933-940.

Szekanecz É. - András C. - Sándor Z. et al. (2006): Malignancies and Soluble Tumor Antigens in Rheumatic Diseases. Autoimmunity Reviews, 6, 42-47. DOI: 10.1016/j.autrev.2006.03.007

Szekanecz É. - Szekanecz Z. (2019): Az onkológiában alkalmazott immuncheckpoint-gátló terápiák autoimmun mellékhatásai: pathogenezis, klinikum és terápia. Orvosi Hetilap, 160, 887-895. DOI: 10.1556/650.2019.31392, https://akjournals.com/view/journals/650/160/23/article-p887.xml

Szekanecz Z. - Szekanecz É. - Bakó G. et al. (2011): Malignancies in Autoimmune Rheumatic Diseases - A Mini-review. Gerontology, 57, 3-10. DOI: 10.1159/000314634, https://www.karger. com/Article/PDF/314634 